\title{
Tradycja - intelektualne muzeum czy struktura komunikacji?
}

\begin{abstract}
Paweł Grad, O pojęciu tradycji. Studium krytyczne kultury pamięci, Fundacja Augusta hrabiego Cieszkowskiego, Warszawa 2017, ss. 278.
\end{abstract}

Mamy, jako filozofowie i filozofki, pewien kłopot $z$ tradycją. Niezależnie od tego, po której stronie sporu stajemy: czy bliżej nam do liberalnego anything goes, czy też do konserwatywnego ubóstwienia dawnych, „dobrze ufundowanych” praktyk i przekonań, pytanie o to, czym właściwie jest tradycja, która atakujemy lub której bronimy, jest pytaniem niewygodnym. Głównym zamiarem pracy Pawła Grada zatytułowanej O pojęciu tradycji. Studium krytyczne kultury pamięci jest zadanie tego niewygodnego pytania oraz próba udzielenia na nie nietrywialnej odpowiedzi. Już pod tym względem jest to książka cenna.

Jest ona cenna tym bardziej, że - podobnie jak samo pojęcie tradycji - podąża w poprzek wszelkich filozoficznych osi podziału. Nie jest to ksiażka wsobna, pisana $z$ perspektywy wybranego przez autora stanowiska filozoficznego - wręcz przeciwnie. Każdy z głównych nurtów współczesnego dyskursu dotyczącego „tradycji” czy "społecznej praktyki” otrzymuje na stronach pracy Grada przynajmniej chwilę uwagi. Jest to zatem książka poruszająca się między wieloma biegunami: współczesnym liberalizmem a konserwatyzmem, heglowska historiozofia i jej postmodernistyczna krytyka, etyka protestancka i katolicka, analityczną filozofią języka a teoria komunikacji Habermasa i (nawet) Jacques'em Derridą. To zderzenie sprawia, że niezależnie od prywatnej afiliacji ksiażkę czyta się bardzo dobrze i umożliwia ona spojrzenie na zagadnienie tradycji $z$ wielu perspektyw. 
Książka składa się z siedmiu rozdziałów i krótkiego zakończenia, prowadzonego w tonie luźnych rozważań dotyczących metapolitycznych implikacji przedstawionej w niej teorii. Choć widać, że jest ona pomyślana jako spójna całość, większość rozdziałów można potraktować jako osobne eseje. W każdym $z$ nich autor stara się przeprowadzić spójną wewnętrznie analizę pojęciową określonego terminu bądź omówić stanowiska w sporze o konkretny aspekt czy uzasadnienie tradycji.

Rozdział pierwszy stanowi wprowadzenie do problematyki: kontekstualizuje książkę jako głos w sprawie problemu tradycji w świecie „posthistorycznym”. Autor już od początku rysuje spór o tradycję jako spór między „projektem postoświeceniowym”, który postrzega tradycję jako „irracjonalną” i jako tako mogąca przynależeć jedynie do sfery prywatnej, a współczesna kultura pamięci, która stara się uczynić $z$ tradycji źródło inspiracji dla nowoczesności jako część historii, z której możemy czerpać. Drugi z tych projektów według Grada ma uzasadnienie zarówno w myśli lewicy, jak i konserwatywnej prawicy - obydwa te uzasadnienia sprowadzaja jednak tradycję do roli służalczej wobec nowoczesności, co wynika $z$ klęski projektu postoświeceniowego, starającego się w imię nowoczesności tradycję przezwyciężyć. Taki projekt jest, według Grada, charakterystyka tradycji jako inspirujacego muzeum; celem autora jest spojrzenie na wartości i cele realizowane wewnattrz niej, co pozwoli głębiej zrozumieć jej relację $z$ nowoczesnością.

Dwa następne rozdziały, podstawowe dla rozważań zawartych w książce, skupiaja się na charakterystyce rozumienia tradycji poprzez projekt kultury pamięci i czerpiąca $z$ teologicznych źródeł analizę Grada. Podejście do tradycji reprezentowane przez kulturę pamięci i filozoficznych myślicieli nowożytnych autor określa jako „konserwatyzm nihilistyczny”. Nie chodzi jednak mu „o publicystyczna obelgę, tylko o filozoficzne pojęcie" (s. 40) - taki konserwatyzm nie widzi bowiem żadnego uzasadnienia dla tradycji i wytwarzanego przez nia porządku społecznego poza samym faktem jego „dawności”. Tego rodzaju konserwatyści, według Grada, definiuja 
tradycję po prostu jako „coś z przeszłości” (s. 35-36): jako przykład służa tutaj analizy pojęcia tradycji przeprowadzone przez Jerzego Szackiego i Edwarda Shilsa. Uzasadnieniem przyjęcia takiej definicji jest wówczas jedynie pragmatyczna konieczność oparcia się w swoim działaniu na jakichś utylitarnie przydatnych zasadach ( $z$ braku bądź niemożności osiagnięcia zasad uniwersalnie prawdziwych), tradycja zaś jest zestawem regul, które przez wzgląd na swoją dawność dowiodły własnej użyteczności. Grad upatruje źródło takiego traktowania i uzasadniania tradycji w systemach etycznych nowożytnych racjonalistów: ciekawie analizuje pod tym kątem pojęcie moralności tymczasowej Kartezjusza oraz „teorię automatu" Pascala. W kontrze do zarysowanych poglądów, w rozdziale trzecim Grad próbuje naszkicować model tradycji jako systemu komunikacji wewnatrz określonej wspólnoty, opierajaccego się na wyróżnieniu określonego zbioru praktyk i przekonań (utożsamionych tu $z$ dyscyplina i doktryna), który każdy członek wspólnoty powinien przestrzegać: „[...] działanie komunikacyjne właściwe wspólnotom tradycyjnym polega na zdefiniowaniu i przeprowadzeniu granicy oddzielającej członków tej wspólnoty od tych, którzy nimi nie sa. Jest to granica określająca właściwe ("ortodoksyjne») przekonania i praktyki, na które musi się zgodzić każdy, kto chce zostać uznany za członka wspólnoty tradycji” (s. 78). Specyfika takiego modelu tradycji będzie charakterystyka tego zestawu reguł jako kierującego się zasadami różnicy i inkluzji: zestawu „maksymalnie jawnych" (s. 81) warunków, których musza przestrzegać członkowie wspólnoty, oddzielająca ich od tych, którzy pozostają poza obrębem tradycji, oraz tych reguł, które musi spełnić potencjalny „konwertyta”, aby do danej tradycji wstapić. Reguły te pozwalaja uzasadnić postępowanie wewnątrz danej tradycji (zapewniaja racje i wyjaśnienia działania), konstytuując racjonalność pewnych praktyk jako realizację określonej „formy życia” - wartości wewnętrznych dla danej tradycji. Grad w tej charakterystyce czerpie wyraźnie i otwarcie $z$ pragmatycznej semantyki Roberta Brandoma wraz z jej reguła make it explicit; pobrzmiewaja $\mathrm{w}$ niej 
też echa teorii działania komunikacyjnego Habermasa i Kanta, późnego Wittgensteina oraz analizy pojęcia racjonalności MacIntyre’a jako wewnętrznej własności określonych systemów wartości.

Rozdziały czwarty, piąty i szósty stanowia próby wyciagnięcia wniosków $z$ podanego modelu tradycji na trzech różnych płaszczyznach. Rozdział czwarty dotyczy sporu między protestanckim i katolickim ujęciem „źródła wiary” i jest historycznie oraz rzeczowo bodaj najciekawszym fragmentem książki. Grad konfrontuje $\mathrm{w}$ nim obecne w kontrreformacyjnej teologii pojęcie tradycji jako „żywego głosu”, podążania za określonymi praktykami i doktryną, w których dopiero może się realizować prawdziwa wiara, $z$ pojęciem protestanckiej „wiary prywatnej”, czerpiacej źródło $z$ lektury Biblii. W przekonujący sposób uzasadnia, dlaczego ta debata może być istotna nie tylko dla filozofów i historyków religii. Autor dokonuje w tym rozdziale rozróżnienia na podejście „historii” (uwidocznione po stronie protestanckiej) i "tradycji” (występujące po stronie kontrreformacji). Ta pierwsza uznaje istniejący zbiór reguł i przekonań za przygodny i nieistotny z punktu widzenia doznania religijnego, którego źródłem jest lektura Pisma, druga zaś uznaje, $\dot{z}$ e to doznanie może istnieć jedynie wewnatrz podobnych reguł. Grad przeprowadza interesująca analizę tych dwóch podejść, osadzając ją we współczesnym kontekście problematyki prywatności doznań, pracach Edmunda Husserla i Ludwiga Wittgensteina. Autor w klarowny sposób wiąże argument Wittgensteina przeciw możliwości istnienia języka prywatnego z krytyka „historycznie” pojmowanej epistemologii doznania religijnego jako niemożliwej do uwspólnienia i przez to również chybionej w swoim założeniu „trzymania się ducha Pisma”. Rozdziały piąty i szósty zasadzaja się na krytyce „historycznych” oraz zaoferowaniu z perspektywy „tradycyjnej” ontologicznych charakterystyk przedmiotu tradycji czy historii („szczątków”, „relikwii” czy „narzędzi”) i podmiotu (gdzie znajdziemy dyskusje $z$ nowożytnym, a zwłaszcza Kantowskim jego ujęciem oraz interesujące odczytanie Arystotelesowskiej antropologii). Rozdział siódmy oferuje natomiast analizę używanego wcze- 
śniej w książce intuicyjnie pojęcia formy życia poprzez pryzmat filozofii Arystotelesa i interpretacji późnego Wittgensteina w duchu Saula Kripkego. Grad wyszczególnia tutaj warunek pozwalający na przekład różnych wartości między tradycjami: konieczną możliwość opisu osoby pozostającej poza częścia wspólnoty jak gdyby była jej częścią, czyli jako kierującej się określona reguła tradycji - dobrze lub źle, ale jej podlegajacca. W ostatnim fragmencie dotyczacym metapolitycznych konsekwencji modelu tradycji, raz jeszcze autor poddaje krytyce obecna „kulturę pamięci” jako negujaca wytwory tradycji lub w najlepszym razie traktujacca je jako obiekty intelektualnego muzeum. Pytanie, w jakim stopniu powrót i obecność tradycji w postnowoczesnym społeczeństwie sa możliwe, według Grada zależy tylko od możliwości przekroczenia takiego jej traktowania.

Książę Pawła Grada charakteryzuje ogromna sprawność intelektualna i językowa: jest ona napisana $z$ moca polemiczna, w sposób ciekawy i jednocześnie stosunkowo przystępny dla czytelnika mającego nawet niewielka orientację w danej dziedzinie filozofii. Wiele potocznych intuicji czy poglądów dotyczacych "tradycji” bądź „tradycjonalizmu” jest w tej książce słusznie wyciagniętych na światło dzienne i przeanalizowanych, co czyni ją interesująca również dla osób, które nie mają w „sporze o tradycję" ustalonego poglądu.

Czytając tę pracę, można jednak odnieść wrażenie dość wąskiego pojmowania tradycji przez Grada. W wielu istotnych fragmentach traci ona walor ogólności, a zaczyna się wydawać obroną i analiza jednej konkretnej tradycji - tradycji Kościoła katolickiego. Próżno niestety szukać w książce przykładów, które uwidoczniłyby, że model proponowany przez Grada stosuje się do szerszej grupy tradycji - kulturowych, narodowych czy plemiennych. Stosowanie słownika teologicznego („konwersja”, „herezja”, „doktryna”) do uniwersalnej - przynajmniej w deklaracji - analizy pojęciowej, choć efektowne, wydaje się największą wadą tej książki, zaciemniająca jej sens chyba także samemu autorowi. Szczególnie zgubny wydaje 
się pod tym względem moment, w którym proponuje on „potraktować pojęcie konwersji jako spekulatywne pojęcie filozoficzne opisujace proces włączenia do dowolnej wspólnoty komunikacyjnej” (s. 83); analiza Grada wyraźnie więc traci, nie podejmując nawet próby wyjaśnienia funkcjonowania tradycji we wspólnotach $z$ definicji nieinkluzywnych (choćby narodowych). Nawet jednak w odniesieniu do tradycji katolickiej takie traktowanie pojęcia konwersji wydaje się chybione: uzasadnienie stosowania reguły różnicy (jasnego formułowania doktryny przekonań i praktyk, odróżniajacych członków wspólnoty od „obcych”) Grad widzi właśnie w uczynieniu tradycji przejrzysta i racjonalna (made explicit) dla konwertyty, nie biorąc pod uwage możliwości zewnętrznego uzasadnienia takiego ruchu jako zapewniającego wewnątrzwspólnotową spójność, co potwierdzałby choćby kontekst historyczny wprowadzania przez Kościół spójnej doktryny i wykładni dogmatów w momentach kryzysu oraz powstawania herezji. Uzasadnienie przez cel wewnętrzny (urzeczywistnianie pewnych wartości przez wspólnotę, zapewnianie racji będących podstawą komunikacji i inkluzję obcych) dla wyjaśnienia mechaniki działania tradycji nie wydaje się wystarczające bez wzięcia pod uwagę uzasadnień przez cele zewnętrzne (dążenie do samozachowania czy politycznej dominacji pewnej wspólnoty), które Grad otwarcie odrzuca.

Innym nieporozumieniem pojęciowym wydaje się w książce Grada dość swobodne wymieszanie pojęcia formy życia w znaczeniu Arystotelesowskim (jako realizacji cnoty życia niedostępnej poza obrębem wspólnoty politycznej) i Wittgensteinowskim (funkcjonujacego poza jakimkolwiek uzasadnieniem sposobu życia, wynikajaccego $z$ konstytucji biologicznej i społecznej tresury). Napięcie to widać zwłaszcza wówczas, gdy rozważana jest kwestia możliwości racjonalnej dyskusji między tradycjami. Choć cały rozdział siódmy jest poświęcony temu, co i w jaki sposób tradycja („forma życia”) ma do zaoferowania wyimaginowanemu konwertycie, wciąż trudno odróżnić tę ofertę od krytykowanego z początku uzasadnienia „nihilistycznego”. Gdzie indziej Grad pisze całkiem otwarcie: „Pobożna 
francuska chłopka w wieku XVII, która idzie na mszę, by oddać cześć Bogu i zasłużyć na życie wieczne, jest członkiem wspólnoty tradycyjnej. Współczesny jej Kartezjusz, który zaleca moralność tymczasowa i trwanie przy religii kraju swojego urodzenia dlatego, że należy się trzymać tego, co zastane, jest konserwatywnym nihilista”". W jaki jednak sposób rzeczone „życie wieczne”, będąc dobrem wewnętrznym danej tradycji, ma być przesłanką $\mathrm{w}$ racjonalnej dyskusji między tradycjami i elementem oferty składanej konwertycie? Widoczna u Grada w jego krytyce Kartezjusza i Pascala niechęć „racjonalizowania” przyjęcia tradycji jako „dawnego, sprawdzonego systemu wartości” oraz próba znalezienia wspólnego, racjonalnego gruntu dyskusji między tradycjami wydaje się nie do pogodzenia, a jedyne, co tak naprawdę skłania konwertytę do przyjęcia pewnej tradycji jest u niego (konserwatywno-nihilistyczny u podstawy) strach przed „nagim życiem” czy pozostawaniem poza obrębem wspólnoty politycznej bądź religijnej. Nie sposób odnieść wrażenia, że według Grada w danej tradycji można się albo urodzić, albo się przed nią ukorzyć, nigdy jednak nie można jej przyjąć na zasadach racjonalnych - sam autor podważa zresztą możliwość istnienia pozatradycyjnej racjonalności.

Co jednak istotne, model przedstawiony przez Grada - tradycji jako systemu praktyk i przekonań, dążącego do wyraźnego oddzielenia sfery wewnątrzwspólnotowej i pozawspólnotowej oraz samodzielnie definiującego wartości i dobra wewnętrzne - broni się bez teologicznego rynsztunku i stanowi poważna propozycję tego, w jaki sposób można postrzegać zjawisko tradycji. $Z$ pewnością słusznym rozłożeniem akcentów w tej analizie jest spojrzenie na tradycję raczej jako na konkretny typ struktury semantycznej, psychologicznej czy społecznej zapewniajacej uzasadnienie pewnym działaniom niż po prostu byt historyczny - wspomniane „coś z przeszłości”. Ta charakterystyka pozwala na bardziej zróżnicowane spojrzenie oraz odsłania wielość uzasadnień obecnych wewnątrz tradycji, które nie sprowadzają się w tym ujęciu jedynie

1 P. Grad, Konserwatyzm jest nihilizmem, „Teologia Polityczna co Tydzień” 2012, nr 49. 
do „dawności” czy „dziedzictwa” (czyli do uzasadnień niemal estetycznych), co jest mylącym, ale częstym, uproszczeniem, z którym Grad słusznie walczy. Jest to więc ważna praca, proponująca nowy kierunek w filozoficznym myśleniu o tradycji i każdy, kto zajmuje się współcześnie problemami tożsamości społecznej powinien się $z$ nią skonfrontować.

Maciej Tarnowski

Maciej Tarnowski (ORCID 0000-0003-3824-4134) - magistrant Międzywydziałowych Studiów Humanistycznych w Instytucie Filozofii Uniwersytetu Warszawskiego. Zajmuje się analityczną filozofią umysłu i języka. 